\title{
DETERMINANTS OF THE AGRICULTURAL PRODUCTIVITY GROWTH AMONG ROMANIAN REGIONS
}

\author{
Camelia Burja $^{1}$
}

\begin{abstract}
Productivity is the synthetic expression of the efficiency with which production factors are being used and mattes the competitiveness of economic systems. This study aims to analyze agricultural productivity growth among Romanian regions. To identify the factors that influenced agricultural labour productivity in terms of the territorial profile, we used a factor analysis model for the Farm net value added indicator on labour time unit. The evaluation of total agricultural productivity was performed by using efficiency scores determined with the Data Envelopment Analysis method. The results highlight the determinants of productivity variations in dynamic and territory.
\end{abstract}

Key words: agricultural performance, regions, productivity, Data Envelopment Analysis

JEL codes: O11, D24, Q12

\section{Introduction}

In Romanian economy, agriculture plays an important role and has profound implications in ensuring quality of life and sustainable development of the rural area. Through a process of continuous assessment of local agriculture, we can identify directions of development that will increase the contribution of this activity to the economic and social expansion of the area on principles of sustainable development.

Romanian agriculture is characterized by a large number of people employed in the sector. Their income and the living standards depend on labour productivity. Therefore, knowing labour productivity and the influence factors is a basic requirement for defining a realistic agricultural policy, which will reduce the gaps in this sector compared to the agricultural performances of other EU members.

Assessing the efficiency of agricultural systems can be performed through various methods: statistical, econometric, mathematical, techniques of financial analysis, etc. Among these, a useful tool is the Data Envelopment Analysis method, which is part of the nonparametric methods for linear programming.

The main objectives of the paper aim the analysis of agricultural productivity and the identification of the influence factors that determine the variation in time and space of this indicator. The analysis was performed by comparing the development regions of Romania.

The analysis of labour productivity used the method of comparing indicators and the method of relational modelling of influence factors, which allowed the characterization of the productivity dynamic calculated as Farm net value added on labour time unit. The variation of this indicator is caused by the impact exercised by various influence factors specific to the phenomenon, such as: technical endowment of labour, the weight and efficiency of the used technical and productive capital.

The evaluation of agricultural performance on development regions was performed with the help of Data Envelopment Analysis (DEA). By using the indicators Farm net value added, Average farm capital and Farm labour, we obtain the general scores of efficiency for the analyzed regions, which ensures the assessment of regional agricultural performance and the differences in competitiveness between regions. At the same time, it also suggests the necessary adjustments for

\footnotetext{
1 “1 Decembrie 1918” University, Faculty of Science, Alba Iulia, e-mail: cameliaburja@yahoo.com
} 
inefficient agricultural systems and provides information to substantiate the strategies of regional development.

The analysis turned to a series of economic and financial indicators specific to farms in each development region, taken from the EU database Farm Accountancy Data Network (FADN) for the period 2007-2008. Romanian is registered with 8 regions within FADN Regions. The available data begins with 2007, the year when Romania accessed to the European Union.

\section{Literature review}

The concept of productivity is defined as the rate of output produced per unit of input used in the production process. Depending of the elements used as output or input, measuring agricultural productivity can be done differently. Outputs can be expressed in terms of physical quantity (vegetal or animal yields), as well as in terms of value (turnover, value added, profit); and inputs can be represented by various production factors, such as property assets, technical capital, natural factors, labour quality. The resulting combination leads to various factors, whose content assesses the ability of physical elements and of the human capital to help create value.

Seen from the perspective of sustainable development of agriculture, the results have economic, social and ecological implications. Authors such as Ball et al. (2005), Hailu and Veeman (2001), Lynam and Herdt (1989), Byerlee and Murgai (2001), Cassman and Pingali (1995), Melfou et al. (2007) etc. have developed productivity indicators to measure the performance and sustainability of agricultural systems.

The productivity of agricultural systems may be calculated as partial productivity of a sole production factor or multifactor productivity (de Alvilez, 2011). Labour productivity plays the most important role within partial productivity because production, incomes and the quality of life of the rural population depend on it. The indicator productivity per employee was also used to analyze agricultural inequality between European regions (Castillo and Cuerva, 2009) or the agricultural efficiency of new member countries accessed to the EU (Istvan, 2008).

DEA methodology allows the analysis of the relative performance of different agricultural systems based on predetermined criteria. Malmquist Total Factor Productivity index (TFP) was used to perform assessments regarding the competitiveness of national agricultures (Coelli and Rao, 2003; Lissitsa et al., 2007; Rasmunssen, 2010). The studies that refer to Romania highlight the low competitiveness of Romanian agriculture due to low efficiency of utilization of production factors. In a study conducted in 44 European countries based on the DEA approach, Rungsuriyawiboon S. and Lissitsa A. (2006) have explained the agricultural performance in EU countries and countries in transition, mapping out their productivity profiles. According to this study, Romania is among the group of countries with a low TFP growth rate. This aspect is also confirmed by Burja (2011), who analyzes the Regional disparities of agricultural performance in Romania in the European context based on indicators caracteristic for farms (agricultural output, utilized agricultural area, labour input, machinery, fertilizers and crop protection expense).

\section{Influence factors for the variation of regional agricultural labour productivity}

Among EU countries, Romania is differentiated by the large number of people employed in agriculture and the highest number of small agricultural holdings. Thus, when Romania accessed to the EU, there were 3931350 farms, exceeding by over 1540390 the number of farms in Poland, which is ranked second. Of these, approximately $90 \%$ cultivate areas sized below 5 ha and only $0.4 \%$ of them cultivate more than 50 ha. Total farm force represents approximately $18.9 \%$ of the total indicator in the EU (Eurostat database).

An accurate image of the position of Romanian farms within EU agriculture can be obtained from a comparative analysis of the elements that characterize the production factors they use. The information needed for the analysis is available in the public database of the European Union, Farm Accountancy Data Network. It includes a wide range of economic, financial and social indicators 
about the situation of "average farms". For Romania, FADN has information for 833980 farms in 8 NUTs 2 regions; all these farms run an economic activity.

Labour productivity is calculated based on the ratio Farm net value added on AWU. It emphasizes the active and determinant role of the labour force within the process of creating value, which combines and uses all the other elements of the capital.

The analysis model of labour productivity monitors the variation in time (years 2007 and 2008) and space ( 8 regions of development) of the indicator and emphasizes the factors that influenced its evolution. Measuring the contribution of factors to the dynamic of labour productivity $\left(W_{r}\right)$ for the region $r$ highlights the influence of qualitative elements of the production structure of farms, such as: technical endowment of labour $\left(\frac{F A_{r}}{T L_{r}}\right)$, share of direct technical capital $\left(\frac{M_{r}}{F A_{r}}\right)$ and its efficiency expressed by the value added by the directly productive technical capital $\left(\frac{F N V A_{r}}{M_{r}}\right)$.

The calculus and analysis model of labour productivity can be decomposed into a number of determinants according to equation 1.

$$
W_{r}=\frac{F N V A_{r}}{T L_{r}} \quad W_{r}=\frac{F A_{r}}{T L_{r}} \cdot \frac{M_{r}}{F A_{r}} \cdot \frac{F N V A_{r}}{M_{r}}
$$

Where for the region $r$, at the level of a farm:

$F A_{r}$ represents fixed assets;

$M_{r}$ - machinery;

$T L_{r}$ - total labour input;

$F N V A_{r}$ - farm net value added.

The productivity change for each region compared to the level of the previous year is determined with the help of the absolute change (equation 2) and the rate of change (equation 3):

$$
\begin{gathered}
\Delta W_{r}=\frac{F A_{1}}{T L_{1}} \cdot \frac{M_{1}}{F A_{1}} \cdot \frac{F N V A_{1}}{M_{1}}-\frac{F A_{0}}{T L_{0}} \cdot \frac{M_{0}}{F A_{0}} \cdot \frac{F N V A_{0}}{M_{0}} \\
R W_{r}=\frac{F N V A_{1}}{T L_{1}}: \frac{F N V A_{0}}{T L_{0}}-1
\end{gathered}
$$

To measure the influence of factors with direct impact on labour productivity, we use equations constructed according to the chain of substitution method (Mărgulescu, 2008):

1. Influence of technical endowment of labour

$$
\Delta W_{r}\left(\frac{F A}{T L}\right)=\left(\frac{F A_{1}}{T L_{1}}-\frac{F A_{0}}{T L_{0}}\right) \cdot \frac{M_{0}}{F A_{0}} \cdot \frac{F N V A_{0}}{M_{0}}
$$

2. Influence of the share of direct technical capital

$$
\Delta W_{r}\left(\frac{M}{F A}\right)=\frac{F A_{1}}{T L_{1}} \cdot\left(\frac{M_{1}}{F A_{1}}-\frac{M_{0}}{F A_{0}}\right) \cdot \frac{F N V A_{0}}{M_{0}}
$$


3. Influence of the performance of the productive technical capital

$$
\Delta W_{r}\left(\frac{F N V A}{M}\right)=\frac{F A_{1}}{T L_{1}} \cdot \frac{M_{1}}{F A_{1}} \cdot\left(\frac{F N V A_{1}}{M_{1}}-\frac{F N V A_{0}}{M_{0}}\right)
$$

The data needed for the analysis are presented in table 1. The Bucharest-Ilfov region has the highest labour productivity, but it isn't an agricultural region and the value of the agricultural production in this region is less than 1\% of the national production's value. Excepting this region, one notices that the highest labour productivity is recorded in the Centre Region and the lowest in the North-East region.

Table no. 1.

Indicators of labour productivity in farms by region - Romania - 2007-2008

\begin{tabular}{|l|c|c|c|c|c|c|c|c|c|c|}
\hline \multicolumn{1}{|c|}{ Indicators } & Years & $\begin{array}{c}\text { Nord- } \\
\text { East }\end{array}$ & $\begin{array}{c}\text { South- } \\
\text { East }\end{array}$ & $\begin{array}{c}\text { South } \\
\text { Muntenia }\end{array}$ & $\begin{array}{c}\text { South- } \\
\text { West } \\
\text { Oltenia }\end{array}$ & West & $\begin{array}{c}\text { Nord- } \\
\text { West }\end{array}$ & Centre & $\begin{array}{l}\text { Bucharest- } \\
\text { Ilfov }\end{array}$ & Romania \\
\hline $\begin{array}{l}\text { Farm Net Value } \\
\text { Added/Anuual work } \\
\text { unit(euro/AWU) }\end{array}$ & 2007 & 1348 & 2296 & 1922 & 1876 & 3044 & 2620 & 4395 & 10847 & 2328 \\
\hline \multirow{2}{*}{$\begin{array}{l}\text { Farm Net Value Added } \\
\text { (euro) }\end{array}$} & 2008 & 3087 & 6450 & 5192 & 4005 & 4536 & 4203 & 6465 & 50820 & 5073 \\
\cline { 2 - 12 } & 2008 & 4267 & 4537 & 4002 & 4345 & 5732 & 5226 & 7291 & 16825 & 4826 \\
\hline Fixed assets (euro) & 2007 & 16439 & 10732 & 27507 & 16075 & 36225 & 19383 & 35967 & 16599 & 21704 \\
\hline & 2008 & 33303 & 33939 & 33880 & 18870 & 47725 & 40914 & 52454 & 101976 & 36664 \\
\hline $\begin{array}{l}\text { Capital tehnic productiv } \\
\text { machinery (euro) }\end{array}$ & 2007 & 2791 & 4721 & 4464 & 4492 & 13100 & 4444 & 9757 & 6507 & 5555 \\
\cline { 2 - 12 }$y$ & 2008 & 4912 & 5814 & 4774 & 4002 & 14888 & 6465 & 11795 & 9955 & 6820 \\
\hline $\begin{array}{l}\text { Total Labour input } \\
\text { (AWU) }\end{array}$ & 2007 & 2,42 & 1,98 & 2,08 & 2,32 & 1,88 & 1,99 & 1,66 & 1,55 & 2,07 \\
\cline { 2 - 12 }$y$ & 2008 & 1,39 & 1,26 & 1,23 & 1,4 & 1,53 & 1,56 & 1,34 & 1,41 & 1,39 \\
\hline
\end{tabular}

\section{Source: EU FADN Database}

By applying the presented model (equations 4-6) results the situation of the contribution of the main influence factors over the variation of labour productivity in agriculture at regional level. The dynamic analysis monitors the absolute and relative deviation of productivity in each region ( $\Delta W_{r}$ and $R W_{r}$ ) and the changes resulted from the action of the determining factors (table 2).

Table no. 2 .

Labour productivity dynamic in agriculture - by regions $(2008 / 2007)$

\begin{tabular}{|c|c|c|c|c|c|}
\hline \multirow[b]{2}{*}{ Regions } & \multicolumn{2}{|c|}{ Productivity variation } & \multirow{2}{*}{$\begin{array}{c}\begin{array}{c}\text { Influence of } \\
\text { technical } \\
\text { endowment of } \\
\text { labour }\end{array} \\
\Delta W_{r}\left(\frac{F A}{T L}\right)\end{array}$} & \multirow{2}{*}{$\begin{array}{l}\text { Influence of the } \\
\text { share of direct } \\
\text { technical capital } \\
\quad \Delta W_{r}\left(\frac{M}{F A}\right)\end{array}$} & \multirow{2}{*}{$\begin{array}{c}\text { Influence of the } \\
\text { performance of the } \\
\text { productive } \\
\text { technical capital } \\
\Delta W_{r}\left(\frac{F N V A}{M}\right)\end{array}$} \\
\hline & $\begin{array}{c}\text { Absolute } \\
\left(\Delta W_{r}\right) \\
\text { Euro/AWU }\end{array}$ & $\begin{array}{c}\text { Relative } \\
\left(R W_{r}\right) \\
\%\end{array}$ & & & \\
\hline Nord-East & 1739 & 129,0 & 3411,5 & $-625,0$ & $-1048,0$ \\
\hline South-East & 4154 & 180,9 & 9095,8 & $-6952,8$ & 2032,2 \\
\hline South Muntenia & 3270 & 170,1 & 2083,4 & $-527,9$ & 1695,2 \\
\hline South-West Oltenia & 2129 & 113,5 & 1770,4 & $-898,2$ & 1253,5 \\
\hline West & 1492 & 49,0 & 1886,8 & $-678,0$ & 286,7 \\
\hline Nord-West & 1583 & 60,4 & 4445,1 & $-2197,8$ & $-676,0$ \\
\hline Centre & 2070 & 47,1 & 3543,0 & $-1357,6$ & $-129,0$ \\
\hline Bucharest-Ilfov & 39973 & 368,5 & 40262,8 & $-35491,4$ & 24273,0 \\
\hline Romania & 2745 & 117,9 & 1704,4 & $-772,7$ & 1593,0 \\
\hline
\end{tabular}

Source: calculated data 
Studying the dynamic of labour productivity in Romanian farms highlights an improvement of this indicator in all regions, the growth rate being $117.9 \%$. There's a positive trend in all the regions, but the Bucharest-Ilfov region stands out. A strong dynamic performance is also recorded in South-East and South-Muntenia, whose high productivity growth rates $(180.9 \% ; 170.1 \%)$ led to significant changes of the farm net value added.

The factor that acted positively over productivity in all the farms was the increase of the technical endowment of labour, which emphasizes that by improving the technical and productive basis of farms in each region, we stimulate the ability of the human factor to create value. Changing the performance of the productive technical capital had different impacts within the regions. In regions such as North-East, North-West and Centre, the fixed assets used in a productive manner didn't generate enough new value and, in time, they diminished farm efficiency. A factor with powerful influence, which impacted in a negative manner agricultural policy in all the regions, was the abatement of the share of directly productive technical means.

\section{Agricultural productivity differences by region - DEA approach}

One possibility to achieve an overall assessment of agricultural efficiency in terms of territory is the Data Envelopment Analysis methodology. DEA is a nonparametric method that allows approaching performance and competitiveness aspects for a series of economic systems, named decision units. In economic practice, Data Envelopment Analysis proved to be a valuable management tool that was the basis of the approach and rationale of the decisions regarding organizational restructuring in various fields and sectors at local, regional and national level (Afonso and St. Aubyn, 2006; Afonso and Scaglioni, 2006; Ylmaz et al., 2009; Sarkis, 2000; Kuosmanen and Kortelainen, 2004; Mittal et al., 2007).

Decision units are characterized by different ways of managing resources, upon which depends the final performance. The DEA model takes into consideration the consumed resources and the results for each DMU and provides a measure of overall performance that can be evaluated based on scores of relative efficiency.

Units with maximum score are enlisted on a margin of production efficiency, becoming reference systems for the other decision units. Having lower efficiency scores than the reference systems, they are identified as being inefficient. The efficiency coefficients can serve for evaluation, comparison and ranking of systems, as well as for establishing measures to improve the performance of inefficient DMUs and for planning their future activities (Sarkis, 2000).

Within the performed analysis, the decision units are the eight development regions for which we collected data from farms with commercial profiles. Their characteristic indicators have an average level so that for each region there is a virtual farm included in the analysis, whose technical, productive, economic and social features are specific for local agriculture.

The successful implementation of DEA methodology depends on the used model, on the variables used as inputs and outputs and on their number. It is necessary for the initial analysis to use a low number of variables, and their gradual increase will show the effects over performance (Cooper et al., 2006).

To establish performance, we selected two input factors and one output factor. The input factors represent the economic and social resources involved by farms in their activity and have meaning for the purpose of the analysis. The economic indicators used as inputs (I) are Farms average capital (working capital) and Total labour force. The content of Farm average capital includes all the technical and material resources used for production, among which are included the permanent capital, the biologic material, fertilizers, water, etc. The observed output variable (O) is the indicator Farm Net Value Added, which expresses the quality of the activity run by farms, measured by its contribution in creating new value (table 3 ).

Table no. 3 . 
Economic and social indicators of farms - by regions of Romania, 2008

\begin{tabular}{|l|c|c|c|}
\hline \multicolumn{1}{|c|}{ Regions } & $\begin{array}{c}\text { O1. Farm net value } \\
\text { added, euro }\end{array}$ & $\begin{array}{c}\text { I1. Average farm } \\
\text { capital, euro }\end{array}$ & $\begin{array}{c}\text { I2. Labour } \\
\text { input, hours }\end{array}$ \\
\hline North - West & 6548 & 34152 & 5169,44 \\
\hline Centre & 8641 & 50658 & 4481,84 \\
\hline North - East & 4293 & 30962 & 4643,74 \\
\hline South - East & 8148 & 33762 & 4138,42 \\
\hline South - Muntenia & 6365 & 29787 & 3930,82 \\
\hline Bucharest - Ilfov & 71907 & 98396 & 4912,82 \\
\hline South - West Oltenia & 5626 & 16144 & 4770,43 \\
\hline West & 6953 & 48874 & 5025,38 \\
\hline
\end{tabular}

Source: EU FADN database

In the first stage, we evaluate the performance of farms according to the value added by using the entire permanent capital in operational activities $(\mathrm{O} 1, \mathrm{I} 1)$. In the second stage, we evaluate farm efficiency according to average farm capital and labour input (O1, I1, I2).

The results obtained by using the output-orientated model variable returns to scale (VRS) and the Win4DEAP software are presented in table 4.

Table no. 4.

General efficiency of farm - by regions of Romania, 2008

\begin{tabular}{|l|c|c|c|}
\hline \multirow{2}{*}{ Regions } & \multicolumn{2}{|c|}{$\begin{array}{c}\text { Technical efficiency resulted from the } \\
\text { output-oriented model DEA (\%) }\end{array}$} & $\begin{array}{c}\text { Efficiency variation } \\
\text { (the impact of the human } \\
\text { factor) } \\
\text { \% }\end{array}$ \\
\cline { 2 - 3 } & $\begin{array}{c}\text { based on average } \\
\text { farm capital (I1) }\end{array}$ & $\begin{array}{c}\text { based on average farm capital } \\
\text { and labour input (I1, I2) }\end{array}$ & \begin{tabular}{c} 
ind \\
\hline North-East
\end{tabular} \\
\hline South-East & 4,4 & 27,2 & 27,1 \\
\hline South-Muntenia & 38,3 & 68,2 & 61,7 \\
\hline $\begin{array}{l}\text { South-West } \\
\text { Oltenia }\end{array}$ & 100,0 & 100,0 & - \\
\hline West & 21,7 & 100,0 & - \\
\hline North-West & 32,5 & 21,7 & - \\
\hline Centre & 25,8 & 32,5 & 3,7 \\
\hline Bucharest-Ilfov & 100,0 & 29,5 & - \\
\hline mean & 48,0 & 100,0 & 11,9 \\
\hline
\end{tabular}

Source: results from DEAP soft

The first version of DEA (where Farm average capital and Farm net value added were taken into account) highlights a margin of production efficiency where only the farms in the BucharestIlfov region and South-West Oltenia region are located; the South-West Oltenia region has the maximum score of efficiency. The farms in the other regions are far behind the farms in the Bucharest-Ilfov and South-West Oltenia regions in terms of performance, having efficiency levels that vary from $21.7 \%$ to $41.1 \%$. They are below the national average of agricultural efficiency based on Farm net value added and Farm average capital, which is $48.0 \%$.

Making an evaluation according to Farm net value added (outputs) and inputs - Farm average capital and Labour input shows a different picture of agricultural performance. In addition to the farms in the South-West Oltenia and Bucharest-Ilfov regions, the farms in the South Muntenia region are also included on the efficiency margin. Only the West and North-West regions don't change their efficiency as a result of the labour input, but for all the other regions, the efficiency variation ranges from $2.8 \%$ (North-East) to $71.7 \%$ (South-Muntenia), the mean of efficiency variation for the whole country being $11.9 \%$. This shows that the labour time for 
production is an element that directly contributes to improving territorial agricultural performance; in some regions the better use of the work time is a reserve for increasing efficiency.

The agricultural efficiency variation in the two types of evaluation shows that the created value depends significantly on the management of labour resources.

Improving regional performance of inefficient farms and enlisting them on the efficiency margin requires a new combination of resource consumption. This solution leads to the idea of reducing resources, such as the permanent, current and human capital, which presently don't generate sufficient value. However, a more thorough analysis shows it should be acted in terms of increasing the efficiency of factors, which will generate additional value added. The productivity growth of the factors involved in agricultural production requires appropriate technical and organizational measures: using skilled and motivated employees, optimizing the size of farms, using advanced technologies and biological material, etc.

\section{Conclusions}

The spatial and dynamic analysis of agricultural productivity emphasized a few aspects that explain the performance differences recorded in the Romanian development regions and the main influence factors.

The analysis used relational modelling of economic and financial indicators with impact over productivity and the efficiency scores were determined with the help of DEA.

The dynamic analysis of labour productivity highlighted the representative factors that have a decisive effect on the evolution of the indicators, such as: technical endowment of labour, the share of direct technical capital and its productivity. The performance of each region was studied on the basis of absolute variation of productivity compared to the level of the indicator in the previous period and the level of the productivity variation resulted from the individual action of influence factors.

The results illustrate the manifestation of an upward trend of agricultural performance in all the Romanian regions, with a more pronounced dynamic in the Bucharest-Ilfov, South-East and South-Muntenia regions.

The factor technical endowment of labour strongly stimulated the performance increase in all the regions, and the efficiency with which the technical means are used also had a favourable impact. An element that diminished productivity in all the regions was the lower share of the productive technical capital.

Assessing the performance of regional agriculture through DEA is based on the outputorientated model variable returns to scale (VRS) applied in two ways.

The first DEA model calculates for each DMU a general efficiency score by using Farm net value added as an output variable and Farm average capital as an input variable. We obtained a territorial allotment of performance ranging from $21.7 \%$ to $41.1 \%$. The gap between inefficient and efficient farms is significant, the South-West and the Bucharest-Ilfov regions recording the highest agricultural performance.

The second evaluation of performance conducted with the help of DEA introduces an additional variable, namely the labour time, obtaining the scores of general efficiency of agriculture. At the same time, we can assess the impact of the labour force over the efficiency of agricultural activities.

The South-West Oltenia, South-Muntenia and Bucharest-Ilfov regions are areas identified as having the highest performance given by Total productivity factor; they compose the reference system for assessing the performance level of the other regions. Ranking agricultural regions according to Total productivity indicates the existence of qualitative differences between the agricultural systems practiced in Romania. The most efficient farms are in the South-Muntenia, South-West Oltenia, Bucharest-Ilfov regions, followed by the South-East region, while the other 
farms have lower efficiency $(21.7 \%-32.5 \%)$; this situation was also highlighted by other studies (Burja, 2011).

Following the consideration of the labour force factor, the efficiency of agriculture increased by an average of $11.9 \%$, in some farms the increase being $61.7 \%$. The results suggest the importance of the human capital within agriculture, the labour force being a production factor that can significantly contribute to increasing efficiency and reducing differences in economic development between regions, which is consistent with the conclusions of other studies (Castillo and Cuerva, 2009).

The need for balanced rural development, consistent with the agricultural model specific to the European Union, requires implementing strategies of sustainable development in each region and introducing measures to increase efficiency into the practice of farms.

Measures to stimulate agricultural development have to primarily stimulate the actions of producers towards investments into the permanent and human capital (Buiter, 2000). This involves aspects such as: expanding the technical and productive base of the farm, improving the extensive and intensive use of the directly productive capital, increasing the motivation of the human factor and improving their skills, using appropriate technologies, creating farms with competitive production capacities, etc.

\section{References}

1. Afonso A., Aubyn M. St., 2006. Cross-country efficiency of secondary education provision: A semi-parametric analysis with non-discretionary inputs, Economic Modelling, Elsevier, 23(3), 476-491

2. Afonso A., Scaglioni C., 2006. An Assessment of Telecommunications Regulation Performance in the European Union. Department of Economics at the School of Economics and Management (ISEG), Technical University of Lisbon, Working Papers, number 7

3. Ball E., Fare R., Grosskopf S., Zaim O., 2005. Accounting for externalities in the measurment of productivity growth: the Malmquist cost productivity measure, Structural change and Economic Dynamics, 16, 374-394

4. Burja V., 2011. Regional disparities of agricultural performance in Romania, Annales Universitatis Apulensis Series Oeconomica, 13(1), 115-121

5. Byerlee D., Murgai R., 2001. Sense and sustainability revisited: the limits of total factor productivity measures of sustainable agricultural systems, Agricultural Economics 26, 227 236

6. Cassman K.G., Pingali P.L., 1995. Extrapolating trends from long-term experiments to farmers' fields: the case of irrigated rice systems in Asia, Barnett, V., Payne, R., Steiner, R. (Eds.), Agricultural Sustainability: Economic, Environmental, and Statistical Considerations. Wiley, London

7. Castillo J.S., Cuerva C., 2009. A Comparison of Agricultural Productivity Among European Regions, Cahiers Options Méditerranéennes, 64, 267-278

8. Coelli T.J., Rao D.S.P., 2003. Total Factor Productivity Growth in Agriculture: A Malmquist Index Analysis of 93 Countries, 1980-2000, Agricultural Economics,.......

9. Cooper W.W., Seiford L.M., Tone K., 2006. Data envelopment analysis - a comprehensive text with models applications references and DEA-solver software, 2nd ed. New York, Springer

10. de Avillez R., 2011, A Detailed Analysis of the Productivity Performance of the Canadian Primary Agriculture Sector, CSLS Research Report 2011-06 (Ottawa: Centre for the Study of Living Standards). http://www.csls.ca/reports/csls2011-06.pdf

11. Eurostat data base, www.epp.europa.eu, accessed in 3.07.2011 
12. Hailu A., Veemen T. S., 2001. Allternative methods for environmentally adjusted productivity analysis, Agricultural Economics, 25, 211-218

13. Istvan T., 2008. Change of asset efficiency in EU agriculture: challenges for new members, European Association of Agricultural Economists, International Congress, August 26-29 Ghent, Belgium.

14. Kuosmanen T., Kortelainen M., 2004. Data Envelopment Analysis in Environmental Valuation: Environmental Performance, Eco-efficiency and Cost-Benefit Analysis, Discussion Paper No 21, Department of Business and Economics, University of Joensuu

15. Lissitsa A., Rungsuriyawiboom S., Parkhomenko S., 2007. How Far Are the Transition Countries from the Economic Standards of the European Union? Measuring Effciency and Growth in Agriculture, Eastern European Economics, 45 (3), 51-75

16. Lynam J.K., Herdt R.W., 1989. Sense and sustainability: sustainability as an objective in international agricultural research, Agricultural Economics, 3, 381-398

17. Mărgulescu D., Şerban C., Vasile E., Stanciu C. A., 2008. Financial Analysis, Bren Publishing House, Bucharest

18. Melfou K., Theocharopoulos A., Papanagiotou E., 2007. Economics and rural development, $3(1), 32-38$

19. Mittal R.K., Dhingra S., 2007. Assessing the impact of computerization on productivity and profitability of Indian banks An application of Data Envelopment Analysis, Delhi Business Review, 8(1)

20. NSSD, 2008. National strategy for sustainable development, Romania 2013-2020-2030, Ministry of Environment and Sustainable Development, Bucharest, Romania

21. Rasmunssen S, 2010. Scale efficiency in Danish agriculture: an input distance-function approach, European Review of Agricultural Economics, 37(3), 335-367

22. Rungsuryawiboon S, Lissitsa A., 2006. Agricultural productivity growth in the European Union and transition countries, Discussion Paper, 94, 1-29

23. Sarkis J., 2000. A Comparative Analysis of DEA as a Discrete Alternative Multiple Criteria Decision Tool, European journal of operational research, 123(3), $108-122$

24. Ylmaz, B., M. A. Yurdusev, Hartmancioglu N., 2009. The Assessment of Irrigation Efficiency in Buyuk Menderes Basi, Water Resources Management. 23(6), 1081-1095 